University of Nebraska - Lincoln

DigitalCommons@University of Nebraska - Lincoln

$5-19-2020$

\title{
Alternatives to High Nebraska Agricultural Land Real Estate Taxes, Part 2 of 2: Like-Kind Exchange
}

Austin Duerfeldt

University of Nebraska-Lincoln, aduerfeldt2@unl.edu

Follow this and additional works at: https://digitalcommons.unl.edu/ageconfarmmgmt

Part of the Agribusiness Commons, Agriculture Law Commons, Entrepreneurial and Small Business Operations Commons, Management Information Systems Commons, Other Business Commons, Other Economics Commons, and the Property Law and Real Estate Commons

Duerfeldt, Austin, "Alternatives to High Nebraska Agricultural Land Real Estate Taxes, Part 2 of 2: LikeKind Exchange" (2020). Extension Farm and Ranch Management. 36.

https://digitalcommons.unl.edu/ageconfarmmgmt/36

This News Article is brought to you for free and open access by the Agricultural Economics Department at DigitalCommons@University of Nebraska - Lincoln. It has been accepted for inclusion in Extension Farm and Ranch Management by an authorized administrator of DigitalCommons@University of Nebraska - Lincoln. 


\title{
Alternatives to High Nebraska Agricultural Land Real Estate Taxes: Part 2 of 2
}

\author{
By Austin Duerfeldt
}

May 19, 2020

In part one of this series of articles, I touched on the idea that, when holding land as an investment, considering alternatives is important. We discussed the process of selling the ground, paying the capital gains and then investing in alternatives such as stocks. Here in part two, we will continue to consider the question of agricultural land being the correct investment for your portfolio but will take a different alternative approach. Now, we will look at like-kind exchanges.

\section{Like-Kind Exchange}

With a 1031 like-kind exchange, we are taking a real property asset and exchanging it for another real property asset. Personal Property exchanges no longer fit under 1031 like-kind exchange (learn more in this 2018 (ropWatch article). What is covered are exchanges in land. These exchanges could be an event like exchanging an inherited piece of farm ground in another state for one closer to home. By using 1031, you are deferring the payment of capital gains tax on the sale of real property. One caveat to remember is, even with land sales, you may still have Section 1245 real property that will be taxable. Things such as tiling, fence, irrigation pivots and other depreciable items will be fully taxable. If the property you are trading for also has 1245 property, the tax effect could cancel out.

\section{Alternative Investing}

What if we decide we no longer want to have farm ground rental property, but wish to get into an apartment business in a downtown metropolitan area? With 1031, we can do that. Looking at the farm ground, the 80 acres was originally purchased for $\$ 160,000$, or $\$ 2,000$ per acre. Today, the ground will sell for $\$ 8,500$ per acre, or $\$ 680,000$. If we outright sell the ground, we have a $\$ 520,000$ capital gain on our hands. With a 1031 exchange, if we trade for real property, in this case a lot of ground for the apartment complex that is also worth $\$ 680,000$, there are no taxes due. Let's go a bit further and say the downtown ground purchase was for $\$ 400,000$. At that point we are looking at a partial 1031 exchange. In this case we have a difference in price of $\$ 280,000$ which will be considered boot and will be taxable.

\section{Consideration for using 1031 Like Kind Exchange}

This is a process. There are steps and guidelines that must be followed in order to qualify for a 1031 exchange. If this process is of interest, it is best to talk to your tax provider now and get an understanding. This especially holds true for transactions that will be partial exchanges. The time frame, once started, is limited on 1031 Like Kind Exchange transactions. You will have 45 days to identify the piece of property you wish to acquire and must acquire that property in 180 days. Working with a 
facilitator is required and, given unforeseen issues that can pop up during title searches, 180 days may be tight in some situations.

\section{Final thoughts on farm ground as an investment}

All financial investments have some risk attached. It is important when building an investing portfolio to diversify your investments to spread and manage the risk to your preference. Farm ground is, and will continue to be, an intriguing investment option. The question that must be addressed is if it is the right investment for you.

Austin Duerfeldt is an agricultural economist and extension educator in the Department of Agricultural Economics. 